Cytogenet Genome Res 1978;21:409

\title{
Human Genetic Mutant Cell Repository Index
}

\section{for Volume 21}

A $(1 ; 7)$ translocation, balanced, from a subject associated with repeated abortions (GM-1356): 175

A $(2 ; 8)$ translocation, balanced, 46 chromosomes (GM-845): Ill

A $(2 ; 8)$ translocation, balanced, 46 chromosomes (GM-846): 112

A $(14 ; 20)$ balanced translocation, 46, XX (GM-982): 174

A $(14 ; 20)$ translocation, unbalanced, from a subject with severe congenital anomalies (GM-981): 173

Deletion in the long arm of chromosome 1 from a subject with multiple congenital anomalies (GM-2025): 176

Regulation of NOR activity in cells with increased numbers of NORs, lack of evidence for: 33

Ribosomal DNA in the lowland gorilla: 1

-------in the orangutan: 1

Robertsonian translocations in the Bovi-dae: 42

-------, experimental induction of: 86

meiotic

segregation

in

mice

car

rying three pairs of: 113

Satellite DNAs in calf, sheep, and goat

chromosomes: 145 Sex reversal factor in mice, meiotic

studies of: 11 Sister chromatid exchange induction by

8-methoxypsoralen plus near UV

light: 184

Tandem translocations, experimental induction of: 86

Techniques:

Acridine orange fluorescence of $\mathrm{X}$

chromatin in cultured human fi-

broblasts: 170 Automated measurements of human

C-band size in family studies: $251 \mathrm{CF}$-banding of human chromosomes:

296 Localization of mouse hemoglobin

genes as a test of the effectiveness

of hybridization in situ: 231 Pachytene as a reference standard for

metaphase banding: 212

$\mathrm{X}$ chromatin frequency and cell density:

139

-----------in cultured human fibroblasts:

170

Y chromatin frequency and cell density:

139 - chromosome, human, variation in

length of: 19 